\title{
Sporosarcina koreensis sp. nov. and Sporosarcina soli sp. nov., isolated from soil in Korea
}

\begin{abstract}
Correspondence
Byung-Yong Kim kimby@rda.go.kr
\end{abstract}

\author{
Soon-Wo Kwon, ${ }^{1}$ Byung-Yong Kim, ${ }^{1}$ Jaekyeong Song, ${ }^{1}$ \\ Hang-Yeon Weon, ${ }^{2}$ Peter Schumann, ${ }^{3}$ Brian J. Tindall, ${ }^{3}$ \\ Erko Stackebrandt ${ }^{3}$ and Dagmar Fritze ${ }^{3}$
}

\author{
${ }^{1}$ Korean Agricultural Culture Collection, Microbial Genetics Division, National Institute of \\ Agricultural Biotechnology, Rural Development Administration (RDA), Suwon 441-707, \\ South Korea \\ ${ }^{2}$ Applied Microbiology Division, National Institute of Agricultural Science and Technology, \\ RDA, Suwon 441-707, South Korea \\ ${ }^{3} \mathrm{DSMZ}$ - Deutsche Sammlung von Mikroorganismen und Zellkulturen GmbH, Inhoffenstrasse 7b, \\ D-38124 Braunschweig, Germany
}

\begin{abstract}
Two Gram-positive, aerobic, spore-forming rods, $\mathrm{F}^{\top} 3^{\top}$ and $180^{\top}$, were isolated from upland soil. A phylogenetic analysis of 16S rRNA gene sequences placed both isolates within the genus Sporosarcina, and showed a sequence similarity of $98.9 \%$ between the two strains and a similarity of approximately $94.6-97.3 \%$ with respect to Sporosarcina species with validly published names. The values for DNA-DNA relatedness between the two isolates and related type strains of the genus Sporosarcina were below $28.0 \%$. For both strains, the major cellular fatty acids were anteiso- $C_{15: 0}$ and iso- $C_{15: 0}$. In both cases, the cell-wall peptidoglycan was of the $A 4 \alpha$ type (L-Lys-D-Glu) and the major menaquinone was MK-7. Diaminopimelic acid was absent from both strains. The genomic DNA G+C contents of strains $F 73^{\top}$ and $180^{\top}$ were 46.5 and $44.5 \mathrm{~mol} \%$, respectively. On the basis of the phylogenetic analysis and physiological and chemotaxonomic data, the isolates represent two novel species of the genus Sporosarcina, for which the names Sporosarcina koreensis sp. nov. (type strain $\mathrm{F}^{\top}{ }^{\top}=\mathrm{KACC} 11299^{\top}=\mathrm{DSM}$ $16921^{\top}$ ) and Sporosarcina soli sp. nov. (type strain $180^{\top}=$ KACC $11300^{\top}=\mathrm{DSM} 16920^{\top}$ ) are proposed.
\end{abstract}

The genus Sporosarcina, which belongs to the family Bacillaceae, was established by Kluyver \& van Niel (1936) for strains that have spherical or oval-shaped cells. The first species of this genus to be described was Sporosarcina ureae, the type species. The second species, Sporosarcina halophila, was described by Claus et al. (1983) but was reclassified within the newly described genus Halobacillus as Halobacillus halophilus (Spring et al., 1996). The species Sporosarcina globispora, Sporosarcina psychrophila and Sporosarcina pasteurii were created by reclassification of Bacillus globisporus, Bacillus psychrophilus and Bacillus pasteurii, respectively, and Sporosarcina aquimarina, isolated from seawater, was also added to the genus (Yoon et al., 2001). More recently, Sporosarcina macmurdoensis, a

The GenBank/EMBL/DDBJ accession numbers for the $16 \mathrm{~S}$ rRNA gene sequences of strains $\mathrm{F} 73^{\top}$ and $180^{\top}$ are D0073393 and D0073394, respectively.

Two-dimensional thin-layer chromatograms of the polar lipids of strains $\mathrm{F} 73^{\top}$ and $180^{\top}$ are available as supplementary material with the online version of this paper. psychrophilic bacterium isolated from a pond in Antarctica, was described by Reddy et al. (2003). In this study, we describe two spore-forming bacteria, $\mathrm{F} 73^{\mathrm{T}}$ and $\mathrm{I} 80^{\mathrm{T}}$, that were isolated from soil in Suwon, Korea, and subjected to detailed phylogenetic, phenotypic and chemotaxonomic analyses.

The two strains were isolated from soil samples by using a dilution-plating technique on trypticase soy agar (TSA; BBL) and cultured at $30{ }^{\circ} \mathrm{C}$ for 2 days. Yellowish colonies were produced on TSA and on nutrient agar (Difco). Gram staining was performed using a Gram-stain kit (Difco) according to the manufacturer's protocol. After incubation for 2 days on TSA, cells were fixed using a glass slide coated with $0.8 \%$ agar (to keep the cells in focus) and observed under a phase-contrast microscope (Zeiss). The following physiological tests were carried out according to Gordon et al. (1973) and Claus \& Berkeley (1986): catalase and oxidase reactions, Voges-Proskauer test, growth temperature determinations $\left(5-45^{\circ} \mathrm{C}\right.$, using increments of $\left.5{ }^{\circ} \mathrm{C}\right)$, determinations of growth in the presence of $\mathrm{NaCl}(0,5,7$,

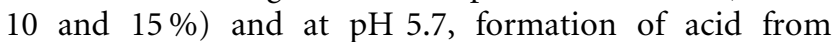


carbohydrates (D-glucose, L-arabinose, D-xylose and Dmannitol), hydrolysis of starch, casein, gelatin and Tween 80 , utilization of citrate and propionate, reduction of nitrate, production of indole, deamination of phenylalanine and the urease test. Motility tests were performed on motility medium $\left(0.1 \%\right.$ yeast extract, $0.01 \% \mathrm{~K}_{2} \mathrm{HPO}_{4}$ and $0.2 \%$ agar). Growth under anaerobic conditions was tested by incubation in an anaerobic chamber (BBL) for 2 weeks.

The cells of strains $F 73^{\mathrm{T}}$ and $180^{\mathrm{T}}$ were Gram-positive and rod-shaped, occurring singly or in filamentous chains. Single cells were $0.5-0.7\left(\mathrm{~F}^{\mathrm{T}} 3^{\mathrm{T}}\right)$ or $0.7-1.0\left(\mathrm{I} 80^{\mathrm{T}}\right) \mu \mathrm{m}$ in diameter and $2.5-3.0\left(\mathrm{~F}^{\mathrm{T}}{ }^{\mathrm{T}}\right)$ or $2.0-3.0\left(\mathrm{I} 80^{\mathrm{T}}\right) \mu \mathrm{m}$ in length. They did not grow anaerobically. In both cases, spores were spherical or oval. However, the cellular positions of the sporangia differed: like spores in described
Sporosarcina species, those of $\mathrm{F} 73^{\mathrm{T}}$ were positioned terminally, whereas the spores of $180^{\mathrm{T}}$ were positioned centrally (Table 1). Cells of strain $\mathrm{F} 73^{\mathrm{T}}$ were motile, but those of strain $180^{\mathrm{T}}$ were non-motile on the medium used in this study. The growth temperature range for strain $\mathrm{F} 73^{\mathrm{T}}$ was $15-40{ }^{\circ} \mathrm{C}$, while that for strain $\mathrm{I} 80^{\mathrm{T}}$ was $15-37^{\circ} \mathrm{C}$. Isolate $\mathrm{F} 3^{\mathrm{T}}$ grew at $\mathrm{pH}$ 6.0-9.0 (optimum, $\mathrm{pH}$ 7.0), whereas isolate $180^{\mathrm{T}}$ grew at $\mathrm{pH} 7.0-9.0$ (optimum, $\mathrm{pH}$ 8.0). Strain $\mathrm{F} 73^{\mathrm{T}}$ grew in the presence of $7 \% \mathrm{NaCl}$ whereas $\mathrm{I} 80^{\mathrm{T}}$ grew in the presence of up to $5 \% \mathrm{NaCl}$. These data indicate that the two isolates are very different physiologically. The two strains were positive for catalase, urease and oxidase and negative for phenylalanine deamination, the formation of indole and dihydroxyacetone, in the Voges-Proskauer test, for acid production from D-glucose, L-arabinose, D-xylose and D-mannitol, and

Table 1. Differential phenotypic and physiological characteristics of strains $F 73^{\top}$ and $180^{\top}$ and type strains of Sporosarcina species

Taxa: 1, strain $\mathrm{F}^{\mathrm{T}}{ }^{\mathrm{T}}$; 2, strain $\mathrm{I} 80^{\mathrm{T}}$; 3, S. macmurdoensis (data from Reddy et al., 2003); 4, S. aquimarina (Yoon et al., 2001); 5, S. globispora (Nakamura, 1984; Rüger, 1983); 6, S. psychrophila (Nakamura, 1984); 7, S. pasteurii (Yoon et al., 2001); 8, S. ureae (Claus \& Fahmy, 1986). All of the taxa shown are positive for catalase activity. +, Positive; -, negative; w, weak; NA, data not available.

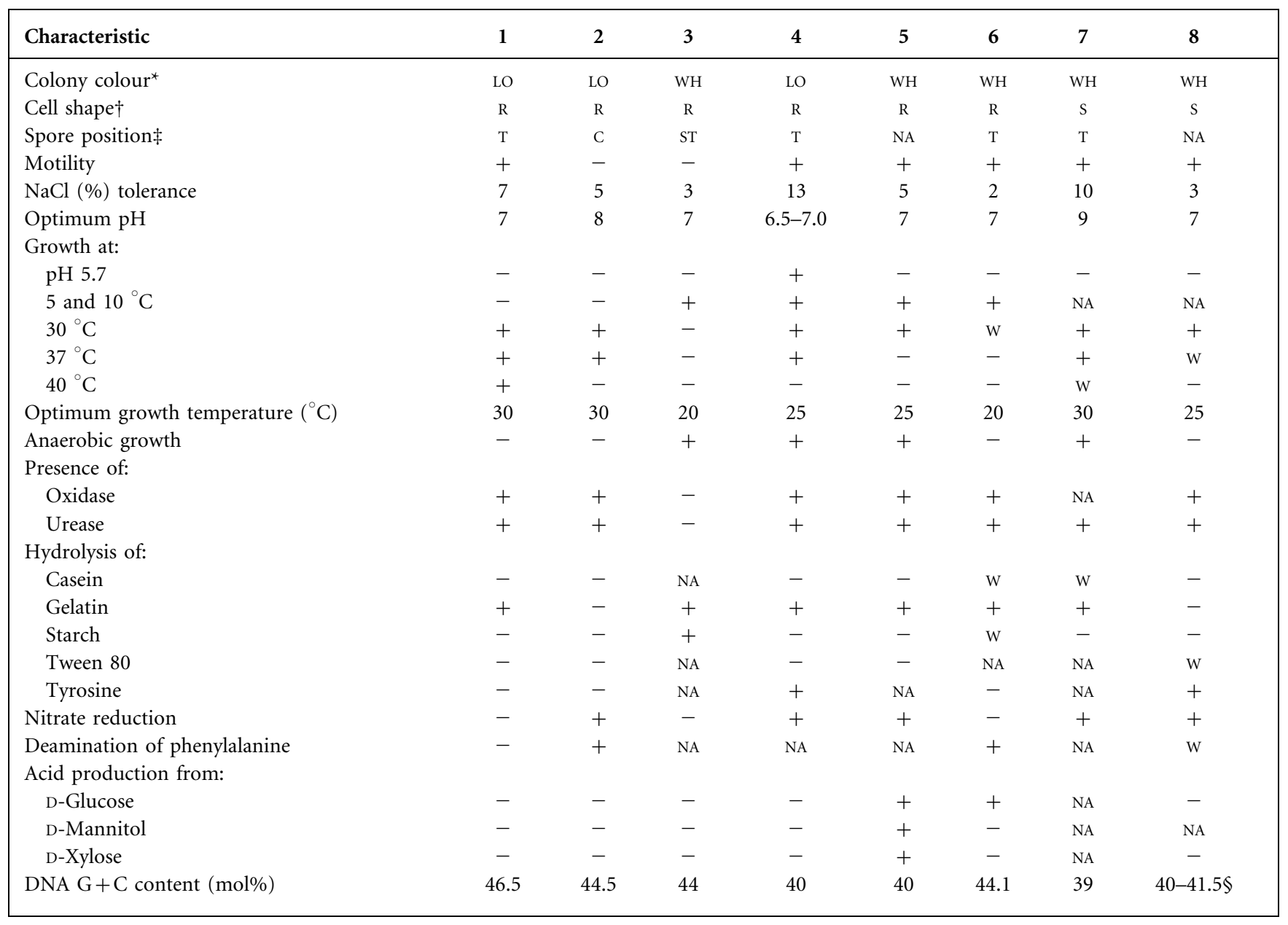

${ }^{\star}$ LO, Light orange; $\mathrm{wH}$, white.

$\dagger_{\mathrm{R}}$, Rod; $\mathrm{s}$, spherical.

‡C, Central; ST, subterminal; T, terminal.

$\S$ Data for 11 strains. 
for hydrolysis of starch, casein and Tween 80 . The detailed results of the physiological characterizations are given in the species descriptions; features that serve to distinguish between the two strains and related Sporosarcina species are listed in Table 1.

Genomic DNA extraction and PCR amplification of the 16S rRNA gene have been described previously (Song et al., 2004). The 16S rRNA gene sequences were analysed using an Applied Biosystems DNA sequencer (ABI 3100). Phylogenetic analyses were performed by using MEGA version 3.1 (Kumar et al., 2004) after multiple alignment of the data by CLUSTAL W (Thompson et al., 1994). Distances were obtained using Kimura's two-parameter model (Kimura, 1980) and clustering was performed using the neighbourjoining algorithm (Saitou \& Nei, 1987). The stability of relationships was evaluated by performing a bootstrap analysis based on 1000 resamplings. The phylogenetic tree indicated that our isolates belong to the genus Sporosarcina (at a high bootstrap value) (Fig. 1). Strain $F 73^{\mathrm{T}}$ showed the highest sequence similarity with strain $\mathrm{I}^{\mathrm{T}} 0^{\mathrm{T}}(98.9 \%)$, followed by the type strains of S. globispora $(97.3 \%), S$. aquimarina (97.2\%) and S. psychrophila (97.2\%). Strain $\mathrm{I} 80^{\mathrm{T}}$ showed the closest relationships with strain $\mathrm{F} 73^{\mathrm{T}}$ (98.9\%) and the type strains of S. globispora (97.2\%), S. aquimarina (97.2\%) and S. psychrophila (96.9\%). Lower levels of sequence similarity $(<96.0 \%)$ were found with species from other genera. Furthermore, five of the Sporosarcina type strains plus $\mathrm{F} 73^{\mathrm{T}}$ and $\mathrm{I} 80^{\mathrm{T}}$ formed a compact cluster with $97 \%$ bootstrap support. Thus, it is clear that these two isolates belong to the genus Sporosarcina.

DNA-DNA hybridization was carried out by using the filter hybridization method (Seldin \& Dubnau, 1985). Probe labelling was conducted by using the nonradioactive DIG-High Prime system (Roche), and hybridized DNA was visualized using the DIG luminescent detection kit (Roche). DNA-DNA relatedness was quantified by using a densitometer (Bio-Rad). The levels of DNA-DNA hybridization between the isolates and related type strains of Sporosarcina species were less than the $70 \%$ threshold value suggested by Wayne et al. (1987) for separate species delineation. Isolate $\mathrm{F} 73^{\mathrm{T}}$ showed low values for DNA relatedness with respect to isolate $180^{\mathrm{T}}$ $(28.0 \%)$, S. globispora DSM $4^{\mathrm{T}}(20.0 \%)$, S. aquimarina KCCM $41039^{\mathrm{T}}(15.2 \%)$ and S. psychrophila DSM $3^{\mathrm{T}}$ $(18.5 \%)$. Likewise, isolate $180^{\mathrm{T}}$ showed low values for DNA relatedness with respect to $S$. globispora DSM $4^{\mathrm{T}}(19.3 \%)$, S. aquimarina KCCM $41039^{\mathrm{T}}(15.2 \%)$ and S. psychrophila $\operatorname{DSM} 3^{\mathrm{T}}(10.0 \%)$.

Analysis of the peptidoglycan structure was carried out as described previously (Groth et al., 1996; Schleifer \& Kandler, 1972). Respiratory lipoquinones and polar lipids were extracted from freeze-dried cell material $(100 \mathrm{mg})$ by using a two-stage method (Tindall, 1990a, b). Biomass for most of the chemotaxonomic studies was prepared following growth of the isolates and standard strains in shake flasks of trypticase soy broth for 3 days at $30{ }^{\circ} \mathrm{C}$; after a purity check, biomass was harvested by centrifugation, washed twice in distilled water and freeze-dried. Wholecell fatty acid profiles were determined using the Microbial Identification system (MIDI; Microbial ID), from biomass grown on TSA for 2 days at $30{ }^{\circ} \mathrm{C}$. The $\mathrm{G}+\mathrm{C}$ content of the DNA was determined by HPLC (Mesbah et al., 1989).

The peptidoglycan of the two isolates contained lysine, glutamic acid, ornithine and alanine [i.e. a variant of the A4 $\alpha$ type, with L-Lys-D-Glu (A11.33; http://www.dsmz.de/ species/murein.htm), as described by Schleifer \& Kandler (1972)]. Neither strain contained diaminopimelic acid as the diagnostic amino acid in the cell-wall peptidoglycan. The predominant isoprenoid quinone was an unsaturated menaquinone with seven isoprene units (MK-7). The polar lipids of strain $F 73^{\mathrm{T}}$ were diphosphatidylglycerol, phosphatidylglycerol, phosphatidylethanolamine, an unidentified phospholipid, an unidentified aminolipid and two unidentified aminophospholipids. Meanwhile, the polar lipids of strain $180^{\mathrm{T}}$ were diphosphatidylglycerol, phosphatidylglycerol and an unidentified phospholipid (see

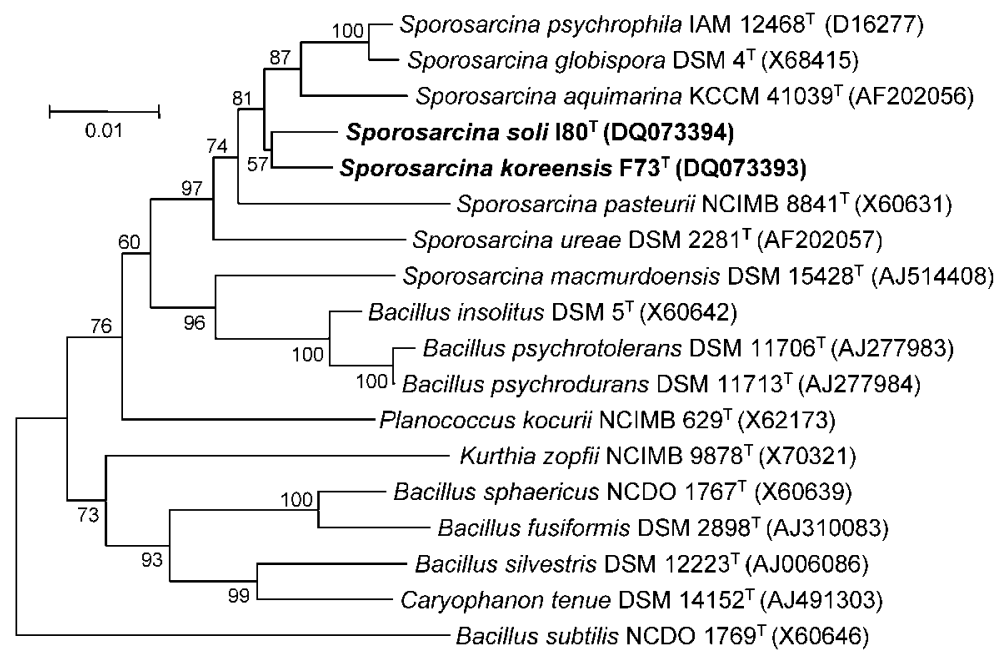

Fig. 1. Phylogenetic tree showing the relationship between isolates $\mathrm{F} 73^{\top}$ and $180^{\top}$ and other strains of the genera Sporosarcina and Bacillus and related genera. The tree was constructed using the neighbour-joining algorithm (Saitou \& Nei, 1987). Bootstrap percentages (based on 1000 replications) above $50 \%$ are shown. Bar, 1 nucleotide substitution per 100 nt. 
Supplementary Fig. S1 available in IJSEM Online). The major fatty acids of the two isolates were anteiso- $\mathrm{C}_{15: 0}$, iso$\mathrm{C}_{15: 0}$ and iso- $\mathrm{C}_{14: 0}$, being similar to those present in species of the genus Sporosarcina. However, the proportion of iso- $\mathrm{C}_{15: 0}$ was much higher in the isolates, differentiating them from recognized species in the genus Sporosarcina (Table 2). The $\mathrm{G}+\mathrm{C}$ contents of the DNAs of strains $\mathrm{F} 73^{\mathrm{T}}$ and $\mathrm{I} 80^{\mathrm{T}}$ were 44.5 and $46.5 \mathrm{~mol} \%$, which are slightly higher than those of Sporosarcina species (Table 1). These chemotaxonomic characteristics, together with the morphological features, also support the affiliation of the isolates to the genus Sporosarcina.

In conclusion, on the basis of the results from this polyphasic study, strains $\mathrm{F} 73^{\mathrm{T}}$ and $\mathrm{I} 80^{\mathrm{T}}$ represent two novel species of the genus Sporosarcina, for which the names

Table 2. Comparison of the cellular fatty acids of strains $F 73^{\top}$ and $180^{\top}$ and type strains of members of the genus Sporosarcina

Strains: $1, \mathrm{~F} 3^{\mathrm{T}} ; 2, \mathrm{I} 80^{\mathrm{T}} ; 3$, S. macmurdoensis DSM $15428^{\mathrm{T}} ; 4, \mathrm{~S}$. aquimarina KCCM $41039^{\mathrm{T}} ; 5$, S. globispora DSM $4^{\mathrm{T}} ; 6$, S. psychrophila KCTC $3446^{\mathrm{T}}$; 7, S. pasteurii KCTC $3558^{\mathrm{T}}$; 8, S. ureae DSM $2281^{\mathrm{T}}$. Data are from Yoon et al. (2001), Reddy et al. (2003) and this study. Only fatty acids accounting for at least $0.5 \%$ of total fatty acid content are listed.

\begin{tabular}{|c|c|c|c|c|c|c|c|c|}
\hline Fatty acid & 1 & 2 & 3 & 4 & 5 & 6 & 7 & 8 \\
\hline \multicolumn{9}{|l|}{$\begin{array}{l}\text { Saturated fatty } \\
\text { acids }\end{array}$} \\
\hline $\mathrm{C}_{13: 0}$ & - & - & 0.5 & - & - & - & - & - \\
\hline $\mathrm{C}_{14: 0}$ & 0.8 & 2.1 & 0.5 & 1.9 & 0.6 & 0.9 & 1.1 & 0.8 \\
\hline $\mathrm{C}_{15: 0}$ & - & - & 1.1 & - & 0.4 & 0.5 & 3.3 & 0.7 \\
\hline$C_{16: 0}$ & 1.1 & 3.6 & 0.7 & 3.8 & 0.9 & 1.5 & 4.7 & 2.1 \\
\hline $\mathrm{C}_{18: 0}$ & - & - & - & 0.5 & - & 0.2 & - & 0.6 \\
\hline \multicolumn{9}{|l|}{$\begin{array}{l}\text { Unsaturated fatty } \\
\text { acids }\end{array}$} \\
\hline $\mathrm{C}_{15: 1}$ & - & - & 1.5 & - & - & - & - & - \\
\hline $\mathrm{C}_{16: 1} \omega 7 c$ & - & - & 1.1 & - & - & - & - & - \\
\hline $\mathrm{C}_{16: 1} \omega 7 c$ alcohol & 1.2 & - & - & 0.2 & 5.5 & 2.4 & 2.8 & 1.4 \\
\hline $\mathrm{C}_{16: 1} \omega 11 c$ & 0.7 & 0.6 & & 0.6 & 3.1 & 1.8 & 3.2 & 2.1 \\
\hline $\mathrm{C}_{18: 1} \omega 9 c$ & - & - & - & 0.4 & - & 0.3 & 0.8 & 0.5 \\
\hline \multicolumn{9}{|l|}{$\begin{array}{l}\text { Branched fatty } \\
\text { acids }\end{array}$} \\
\hline anteiso- $\mathrm{C}_{13: 0}$ & - & - & - & 0.3 & - & 0.1 & - & 0.7 \\
\hline iso- $\mathrm{C}_{14: 0}$ & 6.5 & 6.1 & 11.1 & 3.6 & 3.4 & 4.1 & 15.4 & 2.1 \\
\hline iso- $\mathrm{C}_{15: 0}$ & 44.4 & 36.8 & 4.0 & 5.4 & 4.0 & 6.4 & 6.9 & 7.0 \\
\hline anteiso- $\mathrm{C}_{15: 0}$ & 38.1 & 44.2 & 37.4 & 77.3 & 61.8 & 68.4 & 48.6 & 68.7 \\
\hline iso- $\mathrm{C}_{16: 0}$ & 3.4 & 2.7 & 3.2 & 1.9 & 1.5 & 2.1 & 7.5 & 1.1 \\
\hline iso- $\mathrm{C}_{16: 1}$ & - & - & 22.6 & - & - & - & - & - \\
\hline iso- $\mathrm{C}_{17: 0}$ & 0.7 & 0.9 & 3.0 & - & - & 0.2 & - & 0.5 \\
\hline anteiso- $\mathrm{C}_{17: 0}$ & 1.9 & 2.2 & 13.0 & 4.1 & 6.9 & 6.6 & 4.0 & 8.8 \\
\hline Summed feature $4^{*}$ & 0.5 & - & - & - & 10.6 & 3.9 & 0.7 & 2.5 \\
\hline Unknown fatty acid & - & - & - & - & 0.7 & 0.5 & - & - \\
\hline
\end{tabular}

*Summed features represent groups of two or three fatty acids that could not be separated by GLC with the MIDI system. Summed feature 4 contained iso- $\mathrm{C}_{17: 1} \mathrm{I}$ and/or anteiso- $\mathrm{C}_{17: 1} \mathrm{~B}$.
Sporosarcina koreensis sp. nov. and Sporosarcina soli sp. nov., respectively, are proposed.

\section{Description of Sporosarcina koreensis sp. nov.}

Sporosarcina koreensis (ko.re.en'sis. N.L. fem. adj. koreensis referring to Korea, where the isolates were collected).

Cells are Gram-positive, aerobic, motile, spore-forming rods $(0.5-0.7 \times 2.5-3.0 \mu \mathrm{m})$ that occur singly or in short chains. Endospores are mainly oval and positioned terminally in swollen sporangia. Light-orange-coloured colonies are formed after incubation for 2 days on nutrient agar or TSA at $30{ }^{\circ} \mathrm{C}$. Growth occurs at temperatures ranging from 15 to $40{ }^{\circ} \mathrm{C}$, with optimum growth occurring at $30{ }^{\circ} \mathrm{C}$. Growth does not occur in the presence of $>7 \%$ $\mathrm{NaCl}$. The $\mathrm{pH}$ range for growth is 6.0-9.0, the optimum being $\mathrm{pH}$ 7.0; growth is not observed at $\mathrm{pH} 5.7$ or 10.0. Positive for catalase, oxidase, urease and gelatinase. Negative for anaerobic growth, formation of indole and dihydroxyacetone, in the Voges-Proskauer test, for phenylalanine deamination, nitrate reduction, acid production from D-glucose, L-arabinose, D-xylose and D-mannitol and for hydrolysis of starch, casein and Tween 80 . Does not utilize citrate or propionate. The peptidoglycan is of the L-Lys-D-Glu type (variation $\mathrm{A} 4 \alpha$ ). The major cellular fatty acids are iso$\mathrm{C}_{15: 0}$ and anteiso- $\mathrm{C}_{15: 0}$. The major menaquinone is MK-7. The major polar lipids are diphosphatidylglycerol, phosphatidylglycerol, phosphatidylethanolamine, an unidentified phospholipid and two unidentified aminophospholipids. The $\mathrm{G}+\mathrm{C}$ content of the DNA is $46.5 \mathrm{~mol} \%$.

The type strain, F73 ${ }^{\mathrm{T}}\left(=\right.$ KACC $11299^{\mathrm{T}}=$ DSM $\left.16921^{\mathrm{T}}\right)$, was isolated from upland soil in Suwon, Korea.

\section{Description of Sporosarcina soli sp. nov.}

Sporosarcina soli (so'li. L. neut. gen. n. soli of soil, the source of the organism).

Cells are Gram-positive, aerobic, non-motile, sporeforming rods $(0.7-1.0 \times 2.0-3.0 \mu \mathrm{m})$ that occur singly or in pairs and occasionally in short chains. Endospores are round and are positioned centrally in non-swollen sporangia. Light-orange-coloured colonies are formed after incubation for 2 days on nutrient agar or TSA at $30^{\circ} \mathrm{C}$. Growth occurs at temperatures ranging from 15 to $37^{\circ} \mathrm{C}$, with optimum growth occurring at $30{ }^{\circ} \mathrm{C}$. Growth does not occur in the presence of $>5 \% \mathrm{NaCl}$. The $\mathrm{pH}$ range for growth is 7.0-9.0, the optimum being $\mathrm{pH} 8.0$; growth is not observed at $\mathrm{pH} 5.7$ or 10.0. Positive for catalase, oxidase, urease, phenylalanine deamination and nitrate reduction. Negative for anaerobic growth, formation of indole and dihydroxyacetone, in the Voges-Proskauer test, for acid production from D-glucose, L-arabinose, D-xylose and D-mannitol and for hydrolysis of starch, casein, gelatin and Tween 80 . Does not utilize citrate or propionate. The peptidoglycan is of the L-Lys-D-Glu type (variation A4 $\alpha$ ). The major cellular fatty acids are anteiso- $\mathrm{C}_{15: 0}$ and iso$\mathrm{C}_{15: 0}$. The major menaquinone is MK-7. The major polar 
lipids are diphosphatidylglycerol, phosphatidylglycerol and an unidentified phospholipid. The $\mathrm{G}+\mathrm{C}$ content of the DNA is $44.5 \mathrm{~mol} \%$.

The type strain, $180^{\mathrm{T}}\left(=\right.$ KACC $11300^{\mathrm{T}}=$ DSM $\left.16920^{\mathrm{T}}\right)$, was isolated from upland soil in Suwon, Korea.

\section{Acknowledgements}

We would like to thank Claudia Wahrenburg for her excellent technical assistance. We are also grateful to the anonymous reviewers and the Editor for meticulous reading of an earlier version of this manuscript. This study was supported by the co-research program of the Rural Development Administration, South Korea, and the DSMZ.

\section{References}

Claus, D. \& Berkeley, R. C. W. (1986). Genus Bacillus Cohn 1872. In Bergey's Manual of Systematic Bacteriology, vol. 2, pp. 1105-1140. Edited by P. H. A. Sneath, N. S. Mair, M. E. Sharpe \& J. G. Holt. Baltimore: Williams \& Wilkins.

Claus, D. \& Fahmy, F. (1986). Genus Sporosarcina Kluyver and van Niel 1936, 401 ${ }^{\mathrm{AL}}$. In Bergey's Manual of Systematic Bacteriology, vol. 2, pp. 1202-1206. Edited by P. H. A. Sneath, N. S. Mair, M. E. Sharpe \& J. G. Holt. Baltimore: Williams \& Wilkins.

Claus, D., Fahmy, F., Rolf, H. J. \& Tosunoglu, N. (1983). Sporosarcina halophila sp. nov., an obligate, slightly halophilic bacterium from salt marsh soils. Syst Appl Microbiol 4, 496-506.

Gordon, R. E., Haynes, W. C. \& Pang, C. H. (1973). The Genus Bacillus (Agriculture Handbook no. 427). Washington, DC: Agricultural Research Service.

Groth, I., Schumann, P., Weiss, N., Martin, K. \& Rainey, F. A. (1996). Agrococcus jenensis gen. nov., sp. nov., a new genus of actinomycetes with diaminobutyric acid in the cell wall. Int J Syst Bacteriol 46, 234-239.

Kimura, M. (1980). A simple method for estimating evolutionary rates of base substitutions through comparative studies of nucleotide sequences. J Mol Evol 16, 111-120.

Kluyver, A. J. \& van Niel, C. B. (1936). Prospects for a natural system of classification of bacteria. Zentralbl Bakteriol Parasitenkd Infektionskr Hyg Abt II 94, 369-403.

Kumar, S., Tamura, K. \& Nei, M. (2004). MEGA3: integrated software for molecular evolutionary genetics analysis and sequence alignment. Brief Bioinform 5, 150-163.

Mesbah, M., Premachandran, U. \& Whitman, W. B. (1989). Precise measurement of the $\mathrm{G}+\mathrm{C}$ content of deoxyribonucleic acid by highperformance liquid chromatography. Int J Syst Bacteriol 39, 159-167.
Nakamura, L. K. (1984). Bacillus psychrophilus sp. nov., nom. rev. Int J Syst Bacteriol 34, 121-123.

Reddy, G. S. N., Matsumoto, G. I. \& Shivaji, S. (2003). Sporosarcina macmurdoensis sp. nov., from a cyanobacterial mat sample from a pond in the McMurdo Dry Valleys, Antarctica. Int J Syst Evol Microbiol 53, 1363-1367.

Rüger, H.-J. (1983). Differentiation of Bacillus globisporus, Bacillus marinus comb. nov., Bacillus aminovorans, and Bacillus insolitus. Int $\mathrm{J}$ Syst Bacteriol 33, 157-161.

Saitou, N. \& Nei, M. (1987). The neighbor-joining method: a new method for reconstructing phylogenetic trees. Mol Biol Evol 4, 406-425.

Schleifer, K. H. \& Kandler, O. (1972). Peptidoglycan types of bacterial cell walls and their taxonomic implications. Bacteriol Rev 36, 407-477.

Seldin, L. \& Dubnau, D. (1985). Deoxyribonucleic acid homology among Bacillus polymyxa, Bacillus macerans, Bacillus azotofixans, and other nitrogen-fixing Bacillus strains. Int J Syst Bacteriol 35, 151-154.

Song, J., Lee, S.-C., Kang, J.-W., Baek, H.-J. \& Suh, J.-W. (2004). Phylogenetic analysis of Streptomyces spp. isolated from potato scab lesions in Korea on the basis of 16S rRNA gene and 16S-23S rDNA internally transcribed spacer sequences. Int J Syst Evol Microbiol 54, 203-209.

Spring, S., Ludwig, W., Marquez, M. C., Ventosa, A. \& Schleifer, K.-H. (1996). Halobacillus gen. nov., with description of Halobacillus litoralis sp. nov. and Halobacillus trueperi sp. nov., and transfer of Sporosarcina halophila to Halobacillus halophilus comb. nov. Int J Syst Bacteriol 46, 492-495.

Thompson, J. D., Higgins, D. G. \& Gibson, T. J. (1994). ClustaL W: improving the sensitivity of progressive multiple sequence alignment through sequence weighting, position-specific gap penalties and weight matrix choice. Nucleic Acids Res 22, 4673-4680.

Tindall, B. J. (1990a). A comparative study of the lipid composition of Halobacterium saccharovorum from various sources. Syst Appl Microbiol 13, 128-130.

Tindall, B. J. (1990b). Lipid composition of Halobacterium lacusprofundi. FEMS Microbiol Lett 66, 199-202.

Wayne, L. G., Brenner, D. J., Colwell, R. R., Grimont, P. A. D., Kandler, O., Krichevsky, M. I., Moore, L. H., Moore, W. E. C., Murray, R. G. E. \& other authors (1987). International Committee on Systematic Bacteriology. Report of the ad hoc committee on reconciliation of approaches to bacterial systematics. Int J Syst Bacteriol 37, 463-464.

Yoon, J.-H., Lee, K.-C., Weiss, N., Kho, Y. H., Kang, K. H. \& Park, Y.-H. (2001). Sporosarcina aquimarina sp. nov., a bacterium isolated from seawater in Korea, and transfer of Bacillus globisporus (Larkin and Stokes 1967), Bacillus psychrophilus (Nakamura 1984) and Bacillus pasteurii (Chester 1898) to the genus Sporosarcina as Sporosarcina globispora comb. nov., Sporosarcina psychrophila comb. nov. and Sporosarcina pasteurii comb. nov., and emended description of the genus Sporosarcina. Int J Syst Evol Microbiol 51, 1079-1086. 